\title{
A Rewarding Career in Toponymy
}

\author{
Alan Rayburn
}

Nepean, Ottawa, Ontario

Kandy, Ceylon. ${ }^{1}$ About 1945, when I was 12 years old, the sweet sounds of these two names were observed in an atlas. I dreamed that I might visit them some day. That dream became reality in June, 1959, when I ate a Chinese dinner and had a cup of Ceylon tea in Kandy. It was the embryonic touchstone of a most satisfying career in the study of toponymy.

Throughout my primary and secondary education in Orangeville, Ontario, I developed a deep interest in maps, cultural geography, and Canadian and American history. In 1952, I enrolled in honors history studies at Waterloo College, a satellite campus of the University of Western Ontario, where I was awarded a bachelor's degree in 1956, after having spent my third year at the University of British Columbia. At both Waterloo and UBC, I studied with several erudite professors of history and geography, who whetted my desire to pursue studies of the creation and development of settlements. That desire led me to enroll in 1956 in a master's program in geography at the University of Kentucky, where I received an MA a year later, having written a thesis on the settlement geography of my hometown.

My thesis advisor at the University of Kentucky was Thomas Field. A native of North Carolina, Tom Field lectured on cultural geography, with special attention on the South Pacific. In one of the rooms in the Geography Department, there was an extensive card collection on the place names of Kentucky, which he had assembled over several years. One day, the usually mild and meek Tom Field vented his anger over the naming of Cumberland Gap and Cumberland River. They had been named by explorer Dr. Thomas Walker in the mid-1700s after George II's third son William Augustus (1721-65), the ruthless "Billy the Butcher" at the Battle of Culloden in 1746. The seed was planted in me to pursue the study of place names, if not for a career, at least as an avocation.

Names 49.4 (December 2001):283-287

ISSN:0027-7738

(C) 2001 by The American Name Society 


\section{Names 49.4 (December 2001)}

Toward the end of 1957, I joined the Geographical Branch of the federal Department of Mines and Technical Surveys, ${ }^{2}$ and was assigned to work on those plates of the new Atlas of Canada (1957) devoted to the country's populated places. This introduction to the locations of all of Canada's populated places was a thrilling experience. During that time I "discovered" that the office devoted to collecting and filing Canada's official place names was in the same department, although located in a dreary two-storey prefab structure some four miles away. There I collected the basic details on the populated places of Dufferin County, of which Orangeville is the county seat-and I still have that unpublished manuscript buried away in my filing cabinets.

From June 1958 to May 1959, I worked on land-use and shoreline studies in the three Maritime Provinces. When the Photographic Survey Corporation ${ }^{3}$ of Toronto needed a land-use specialist in 1959 to participate in an extensive natural resources survey of Ceylon, they approached the Geographical Branch to find out if a staff member could be seconded to it for a two year-period. I was chosen, and as it turned out, completed the land-use survey in 15 months, and a beautiful hand-colored landuse map at the scale of two-miles to the inch was presented to the Ceylonese government. Six months after my arrival in Colombo, Ceylon, I met my Irish-born wife, and we were married the following September in Armagh, Northern Ireland, the ecclesiastical capital of all Ireland.

On my return to Canada in 1960, I was assigned to projects in economic geography and land use, and these studies continued until 1964, when I was transferred to the newly created Toponymy Division, and became the first toponymic researcher in Canada. On learning that two geographers would be evaluating the land capability of Renfrew County, an area of 2,950 square miles, west of Ottawa, I proposed a parallel toponymic study. That study revealed a $15 \%$ error factor among the official names, and resulted in the collection of many established names not previously recorded. The book Geographical Names of Renfrew County was published in 1967. Twenty-two years later I republished the book privately, with many corrections and changes to the original text. 
In 1965-66, toponymic surveys were undertaken in several other counties in Eastern Ontario. Hundreds of corrections and new names were recommended to the Ontario member of the Canadian Permanent Committee on Geographical Names ${ }^{4}$ for approval. As a result of the reports on the poor quality of Ontario's geographical names, the province decided to establish the Ontario Geographic Names Board in 1969.

In 1967, my family was moved to New Brunswick, where, over a period of 24 months, I undertook a comprehensive study of the province's names, both in documents and through field interviews. The original stock of names amounted to about 7,500 names. Some 8,000 additional names were added to the official records. I recall writing to Meredith (Pete) Burrill to get advice on what to do with the name Two Brooks, which described a single brook with two long branches. With all his experience and wisdom, he urged me to accept the name as used by the local population. He remained my mentor for several years after. In 1975, Geographical Names of New Brunswick was published. It was during breaks in the fieldwork that I thoroughly read George R. Stewart's Names on the Land. For a payment of $\$ 2.45$, the Susan Eaker Bookshop in Helena, MT sent me the 1967 paperback copy. I had sent $\$ 3.00$, and received the book plus stamps equal to the value of 34 cents.

Following the study in New Brunswick, I undertook a names survey of Prince Edward Island, which, at 2,184 square miles, is Canada's smallest province. In honor of the province's entry into Canada in 1873, Place Names of Prince Edward Island was published in 1973.

In 1970, I enrolled in a doctoral program at Laval University in Québec City, where there were four others taking postgraduate studies in choronymy. ${ }^{5}$ I completed the course work, but did not write a planned dissertation on the geographical distribution and characteristics of generic terminology (e.g., butte, coulee, portage, prairie) of French origin in western Canada.

From 1973 to 1987, I was the chief of the Toponymy Division and the executive secretary of the CPCGN. During that period I attended three United Nations conferences on the standardization of geographical names, and about a dozen meetings of the United Nations Group of 


\section{Names 49.4 (December 2001)}

Experts on Geographical Names, serving as its rapporteur from 1977 to 1987. One recollection that stays with me was the considerable debate when the Chinese delegation proposed the adoption of the Pinyin System for the transliteration of Chinese names into Roman script at the third conference of the UNCSGN in Athens in 1977. Both the United States and the United Kingdom vigorously defended the continued use of the long established Wade-Giles System, but they were soundly defeated. The chair of the Canadian delegation that day chose to abstain-we did not embarrass our friends. Almost immediately, government institutions, libraries, and atlas producers, especially those in the United States and the United Kingdom, as well as those around the world, adopted the new system.

In 1974, I became the secretary-treasurer of the Canadian Institute of Onomastic Sciences, which was renamed the Canadian Society for the Study of Names in 1977. I served as its president from 1979 to 1982. I have continued to support the CSSN, and have presented a paper at almost every annual meeting over the past 30 years.

In 1973, I attended a meeting of Wallace McMullen's Names Institute at Columbus Circle in New York, and there Don Orth and I formed a lasting friendship, joining together at names meetings some two or three times a year since then.

I was elected to the Board of Managers of the American Name Society in 1979, served as a vice-president from 1982 to 1984, and was elected president in 1985. The interaction and debate among onomastic scholars at the Society's annual meeting has given me considerable pleasure over the years.

Canadian Geographic invited me in 1983 to contribute a regular column about place names. The column continued until 1996, when 75 essays had been published. The book Naming Canada was published by the University of Toronto Press in 1994, with 61 of the original columns, and a second edition was published in 2001 with all 75 columns, revised and enlarged, plus one more article on Toronto's nickname, Hogtown.

In 1997, Place Names of Ontario was published by the University of Toronto Press and the Dictionary of Canadian Place Names (hardback 
only) was produced by the Oxford University Press of Canada. The latter was republished in 1999 in paperback.

As many of my friends know, I maintain an abiding passion in the study of Canadian places and their names, and take much pleasure in helping others find where elusive names of places were located. Toponymy has provided a most rewarding professional career, both with the Canadian government and privately. The fruit is revealed in 10 published books and 150 articles.

\section{Notes}

1. Ceylon became an independent country in 1948 and changed its name to Sri Lanka in 1972 . With an area of 25,332 sq. mi., it is slightly larger than West Virginia.

2. It was known as the Department of Energy, Mines and Resources during most of my career, but was renamed Natural Resources Canada in 2000.

3. Subsequently known as the Hunting Survey Corporation.

4. Founded as the Geographic Board of Canada in 1897, it was renamed the Canadian Board on Geographical Names in 1948 and acquired the cumbersome name of Canadian Permanent Committee on Geographical Names (CPCGN) in 1961. That name remained until 2000 , when it was changed again, to the Geographical Names Board of Canada.

5. A word devised by the Geography Department's Groupe d'étude de choronymie et de la terminologie géographique to embrace all named phenomena, including not only toponymy, but also wind names, ocean current names, and other feature names not embraced by toponymy itself. 